\section{Herman Bang - 150 år}

It sementorsker, dr. pliil. Knud -1rne Jïritnstn,

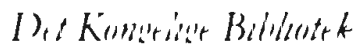

$\mathrm{I}$ anledning af 150 aret for Herman B.angre forlecl udhommer i 213$)^{-}$tre monongratier om hane liv og virke, der 1 vol udetrichning bygeger pa kildematerialer 1 I ect Kongelyge Bilolioteks samlinger.

Herman Bang 1857-1912, blev fordt 1 en prostefumilie i dserballe pa Als or doxle under en eplaxningrsturné jurden rundt pa houptalet i () grden, Ltah, LSA. bllerede 1 lolect af sin studietid pabegyndte han en harriere som journalist og forfatter, s.amtiding med at han forsogrte sig som shuespller eng likhedes som scencinstruktorr.

Han debuterede 4 m litte

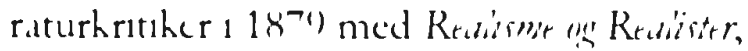

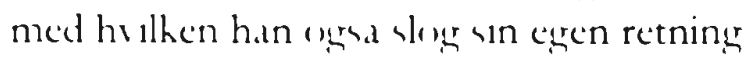
1 litteraturen fast. Iret efter udgals han den forste if monge norellesamlinger, Tan, W' in' r, age den shandalerombruste roman

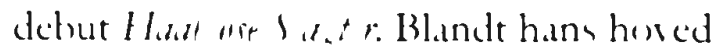
werker han velerligere now nes den trageshe

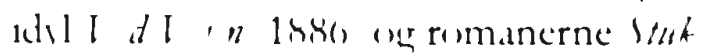

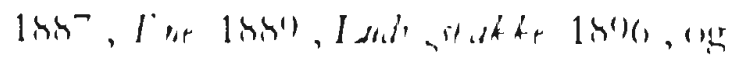
I) thadt Hor lois .

\section{Bang i satirens troldspejl}

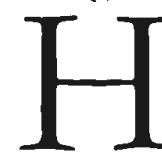
erman Baner ar dene meget andet oge mere end en af vore storste impresmonistake forfittere.

I a hunstnere fil et a bredt on alsedent sirhefelt, we endnu ferre vahte med deres blotte fremoning sa megren opmoth som hed ogr offentligt postyr omkring sit liv, som netop han.

Professionelt spixndte han umadeligt vidt - forfatter, journalist, kronikor, essayist, sceneinstruktur, oplatser og anmelder - og hans produktivitet pa disse felter var enorm.

Bang bler af samme grund sin tids yndlinguroffer $\mathrm{i}$ en lang rixkke vittighedsblade ogr matte gang pa gang betale en endog meget hoj pris for sin berommelse. At samle og presentere denne side af datidens modtagrelse af Bangs kunstnerpersonlighed, bliver derfor ikke kun en ganske underholdende billedsanling, men cos a et stykke alternativ litteratur-, teater-, or pressehistorie om en af de storste d.anske kulturpersonligheder i nyere tid. Vi kan her laxe noget om denne forfatters optreden i sin egen tid samt om den udprexcede grad af ironisk, ja undertiden narmest spottende made, vi danskere ind imellem har modtaget nogle af vore storste forfattere og kunstnere pa.

$$
\text { Kart - eller i denne sammen }
$$

hung mashe nurmere "uhxert" - barn har wom behendt mange nar ne. Pressens harihaturtegnere udr iste da rasa en sicklen stor opfindusembed og hreater itet, n.ar det har grjaldt om at latterliggrore det brede virhefelt, sum forfatteren, juurnali sten, essiysten, anmelderen, instruhturen, "placeren, forcodragsholderen, shuespl leren, shribenten or levemanden Herman Bangr udfordrede un samed med. Lace blet nougle fal at de manere henar neleer man deneraner omtalte ham med:

"Herman Banh", "Herman Labane", "Herman Banew", "I rohen Her menc Bane", "Buner Bang", Herman (in) Bane", "Herman Planh", "Hermanuen Bane", "Herman wn Bremen", "Herman Br.and", "Laken Bane", "Herman Ban 


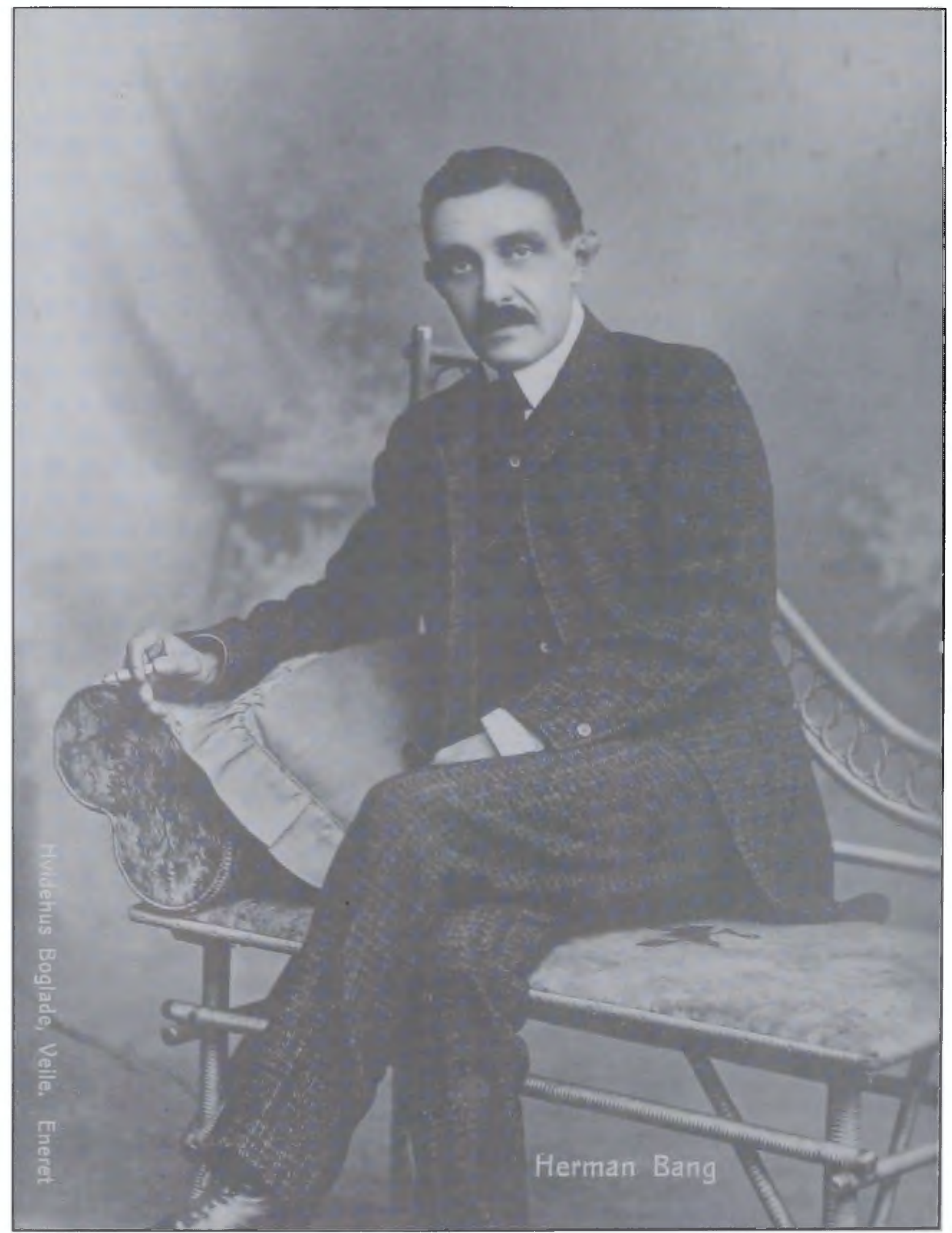

Herman Bang (1857-1912) (Det Konqelige Biblintek).

bang", "Norman Bang", "Grev Herman" og "Hermann von Bangemachen"

Gennem sin lange karriere spillede Bang som kun fa băde med $i$ og spilledes af de moderne medier. Man kan derfor ogsa hæude, at netop han levede for. 
med, a ceg at pressen. "... De er ju sa nem!

() I I em han jeg" starede en hans journalwetrhe plageander ham saleder en gang $\mathrm{i}$ en samtale, hor Bang sele harde beklaget sgorer uge effer uge at blive giort nar af 1 pressen. Der var altid en historie, der hunne knyttes til Bang, ag hor han end ber degede sign, og hrad han end giorde, shabte han det man dengang med et helt nit ord haldte "Reklane" - sacel frivilligt «m ufrulligt.

Sels manorrerede han sig med stur taeft ind 1 presene sugelys. Men den bles dogeramtkdier hans egren storste fiende. P'a et sent tadepunhe udtalte han sele, at "Karihaturerne har varet tor manere ag torerode" for dersed at fortalue, hoorfor han lanet om lange upgar drommen om

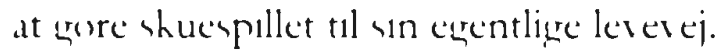
De manece parider a latterligerorelser hes derfor bageden af den ionefaldende

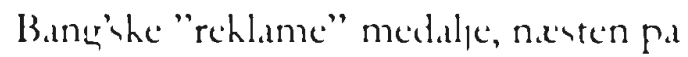
ramme made, som hrediturerne are de

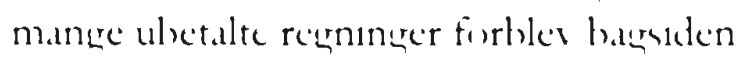
af den chotrad arante on luhsurase facade, han vedhler at udetelle 1 det offentlere rum. Dette heredede ham pa alle mader dirt area pa det prosite plan. I)et rar a.ledes pa mere end en make wart at , it huneneren ar bureceren "Herman Bane".

\section{Reporteren Herman Bang}

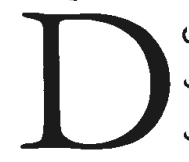
en unere danshe forfiater a ar fra starten en weritalel shrue hach eprute. Pa rehordend fih han slact

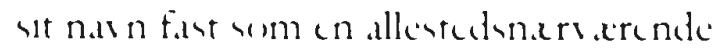
reporter, anmelder, litteraturfiomsller,

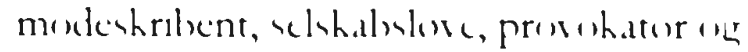
shuesplfierfatter. Han shes om Kolen

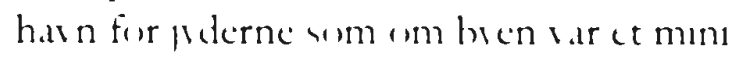
Parse, han beretede om ummerfiurnopleder age seceets shandaler, morrhabuteatre ener modeluner, radedelole ar randhure, carhus forestillingrer og kjolesnit, Tivoli, Dyrehavbakken, gxistespil og royale rygter - og grundligde dermed ikke mindst sit stampublikum af iswr kvindelige lexsere. Herudover lynlexste Bang den aktuelle franske litteratur og introducerede det danske lasepublikum for fremtraxdende forfattere og dramatikere som Émile Zola, Alexandre Dumas den yngre 'se Honoré de Balzac.

Bange emnevaly og skrivestil var bade et frisk og frickt pust i den storede og traditionelle journalistik i de hiemlige hovedstadsaviser, der som udpreget maskulin meningrepresse primart orienterede sig mod erhvervalivet ong de wldumme politiske brydninger, sum karakteriserede Danmark gennem konseil spresident Estrups lange regeringeperisde under de adaddte "Pros isorie ar", hoor folkesty ret reelt war sat ud af hraft.

I Bangs sondayshronikher under fallestitlen "Vehelende Themaer", ladede han de allerforste spirer til det, der forst ombring arhundredsheftet shulle hlive tel den moderne umnihusdrs. Han shere her em stert on smat, sladder en

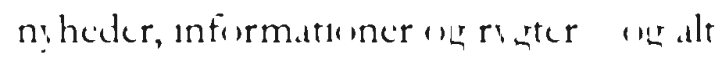
ammen a san exen clegante spresterne, der pa en eane hunne rare sifietileret, hruhbet os indimerende, men alnd nurrarende.

Han hunne firr chemenel indlede en artihel 1 pataret lirerenl neal urd rom "hare I rue" cller "Badere I rue". Ixnne alenle ace appel til netepdethon delinc puthlihum, wim pracer manure af han hrombher, shaffeck ham 1 urtest den hanlige hekencle "Damernes Hermian B.ane". Men den shaffede oreden marhant

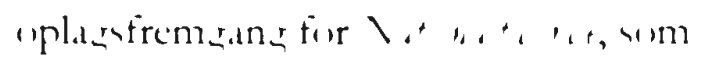

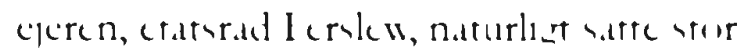

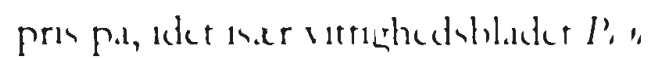


bidrog til denne oplagsstigning ved nærmest hver eneste uge at være parat med en dugfrisk parodi pả Bangs nyeste aviskronik-pähit.

\section{Performeren Herman Bang

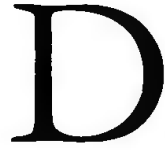 e uhyre produktive forfatterăr $\mathrm{i}$ 1880 Jerne repræsenterer nok det forste og storste hojdepunkt $\mathrm{i}$} Bangs litterære produktion, hror han perfektionerer den impressionistiske skrivestil, hris indflydelse pả dansk litteratur næppe kan vurderes hojt nok.

Bangs antydende fortælleteknik, der med hans mange næsten sceniske beskrivelser og de lynhurtige replikskifter med sigende pauser og tankeprikker nærmest viser situationerne i en billedsproglig form, snarere end de skildrer $i$ ord. Denne fortællestil blev saledes nærmest kvalitetsnormen for hele det tyrende àrhundredes danske litteratur.

Bedommelsen af Bang som dramatiker er dog mere sammensat. Dette kan maske vække undren, nầ man tager $\mathrm{i}$ betragtning, at netop han frem for sà mange andre forfattere mestrede at beskrive og "aftegne" sine medmennesker gennem det de siger og den mäde de gestalter sig pà. Bang udtalte engang selv i en samtale med redaktoren og dramatikeren Palle Rosenkrantz om hans manglende talent for at skrive egentlig dramatik:

"Jeg kan ikke, det lyder fuldkommen latterligt, men jeg kan virkelig ikke".

At han folte sig draget mod teatret og selv sogte scenen lige fra sin offentlige debut er derimod uden for enhver tvivl. Latterliggorelsen af ham bliver dermed ikke mindre respektlos, idet det her var den feminine, krukkede og pinlige forfatterpersonage, der skulle trynes.

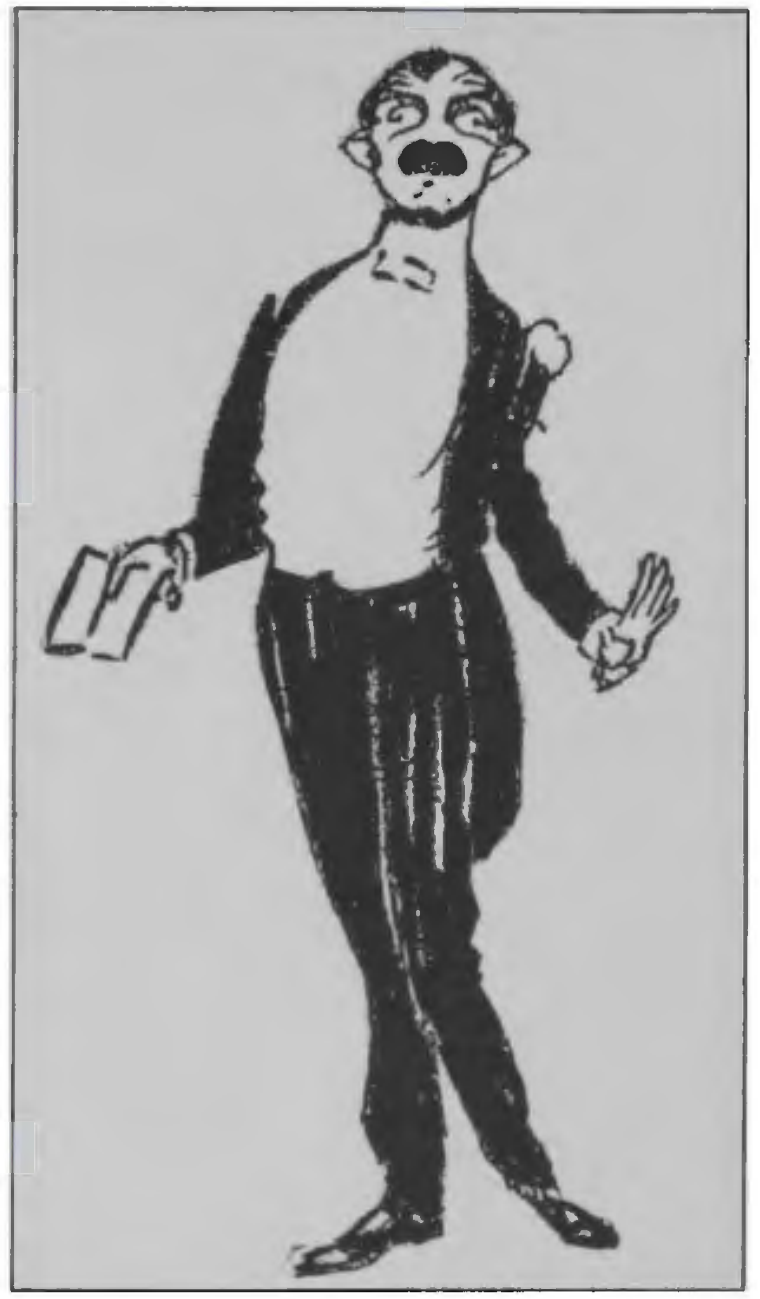

Satirisk, tegning af Herman Bang, der oplaser egne varker pa badebotellet Marienlist ved Helsingar. Tegning of Sophous Jïryensen trykt $i$ Ekstrabladet 10.7.1905 (Det Kongelige Bibliotek).

Især Bangs mange offentlige foredrags- og oplæsningsaftener af egne værker fik straks satiren frem i sædet. I begyndelsen af 188(')erne indleder han saledes den oplæsningsvirksomhed, der skulle blev en fast del af hans liv og en afgorende indtægtskilde i mange ar. Den forte ham rundt i Danmark, Skandinavien, Tyskland, Frankrig, ()strig, Rusland og til sidst Amerika.

$\mathrm{Pa}$ disse foredragsaftener talte Bang om rigt varierede emner, men dog oftest med et litterært eller teatermæssigt indhold. Hans oplæsningsaftener bestod 
derimed nosten altid af uddrag af egne romaner, noveller ogr foljetoner.

Bang fandt med disse optrxdener maske ind til det fuldgryldigrste udtryk forr sine scenishe er ner. Hans spinkle oy aparte fy siske fremtoning, der halde varet den storste anstesdssten for en egentlig karriere som skuespiller, blev her med succes rende til en form for personlig retfixdiggurelse orer for publikum.

De mange heretninger fra sjenvelner til dese oplesningsaftener fortecller saleder alle om hans helt usxedvanlige greb om sit publikum og den sjacldne naturleghed i hans diktoen, hourmed han wergih de fleste af datidens scenckunstnere. In af de bedste beskriveleser af Bange foredrarshunst finder vi i kultur-

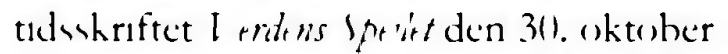
19114, hoor bladets redahter, inders WE: Ifolm, hommer ind pa denne sarligre Bang'she oplasningshunst, som kunne spende fra det urkomstee eng grosteste til de mest ledenshabelige uderyk for men nesheligr smerte org lidelee. Det hedder her:

( )plasning er et shidt ()rd, det passer slet ihke. Ne'1, det, Herman Bamb giorele, war at gennemepille de Scener, han harde pad st Program. Han spllede sels alle Rollerne, on sada mixegtegt var hans Ta lent, at det lykhedes ham at illudere, shent Publikum sad Insigt til Insigt med hans axe, lille Perom, um Bladene har giort (irm med og Karshaturtegnerne fraddet 1. Bedet er han, nalar han laver ganle Damer,

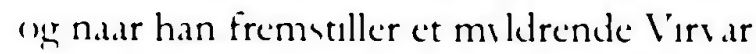
af alle Slage Mennesher, der taler 1 Munden paa hinanden. I n Betonnge, en Ber xegelee, en Ansygterynke, der siger alt; af saa sma Midler er det, at Hermasm Basmishaller den store Virhning. Ciller han shiklerer Smerten, Lidclenen. ()graa dern er han fuldtem men sikker paa sine Midler [...] ()g der

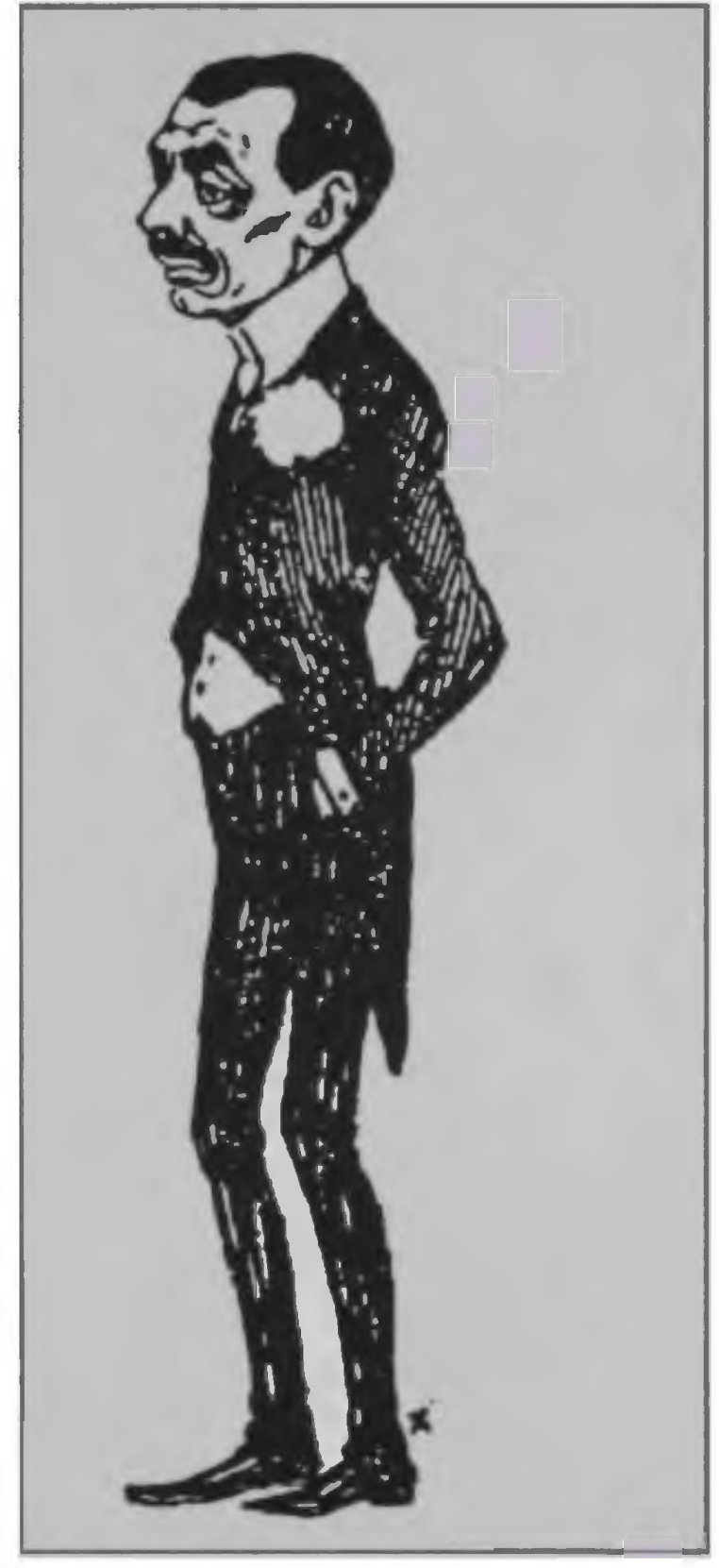

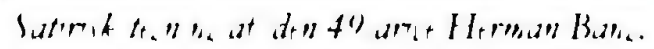

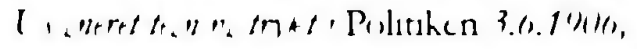

er talrige I hecmpler pal hans Mast oser sindene, hwor han weer ye sim smertens

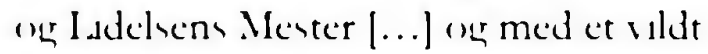
Rasern vender man we truende mod Firrinet, der har fildt Teatre med erede shihhelser uden Indmad ar ladet dette secenen (iene vare forbandet tol en ube hiclpelig Kropsloshed. 


\section{Teatertænkeren Herman Bang}

$\mathrm{I}$ Paris arbejdede Bang hovedsageligt som sceneinstruktor og introducerede her det franske publikum for tidens aktuelle nordiske dramatikere som Henrik Ibsen og Bjornstierne Bjornson. Deres internationale gennembrud fik han dermed en ræsentlig andel $i$, for hrilket de begge blev ham dybt taknemmelige. Flere af Frankrigs teaterprimadonnaer fik han nu personlig kontakt med, bl.a. Sarah Bernhardt og ikke mindst Gabrielle Réjane, for hvem han instruerede rollen som "Nora" i Ibsens revolutionerende skuespil Et dukkehjem.

Bangs mangeảrige praktiske teaterarbejde - han nåede at iscenesætte over 80 teaterforestillinger - ledte til en ligeså indgående beskæftigelse med scenekunsten pá det teoretiske og intellektuelle plan.

Lige fra sine unge år skrev han - ofte under mærke - talrige overordentlig interessante artikler, hvoraf flere i dag stadig fortjener at blive genoptaget, belyst, analyseret og kommenteret. Det er i disse artikler tydeligt, at det ikke blot var det praktiske instruktorarbejde på teatret, men netop denne omfattende essayistik om teatret og scenekunstens væsen, som ansporede Bang til hele det efterfolgende store forfatterskab.

Det, som måske lå ham mest på sinde med sin teater-essayistik, var nok at understrege, hvorledes scenisk naturalisme mere udgor en kunstform end en xstetisk tendens - eller med andre ord: en art dramatisk sandhedskunstskole. I sine mange teatermæssige essays er det derfor lige sà meget Herman Bangs fine blik og sans for scenekunstens detalje som hans onske om at trække de store linier op, der er det fremtrædende.
Det samme gælder for hans dramaturgiske kritik og de mange indgående kunstner- og skuespillerportrætter, der i flere tilfælde stär tilbage som nogle af datidens absolutte teaterkritiske hojdepunkter.

Bangs teateressays er tillige yderst varierede med deres indgàende overvejelser om teatrets, instruktorens, skuespillerens, kritikerens og publikums funktioner, og de indgàende analyser han fremlægger af sável trykte dramatekster som egentlige sceniske forestillinger.

Alle aspekter af teaterprocessen $i$ det moderne gennembruds tid er med andre ord her blevet gennemanalyseret af en af datidens forende teatermænd og litterater.

Som teatertænker og essayist kommer Bang rundt om să godt som alle scenekunstens aspekter. Fra mere generelle og overordnede betragtninger om dramaturgisk kritik, bevæger han sig i hundredvis af essays og feuilletoner ind på skildringer af să vidt forskellige emner som "psykologisk Skuespilkunst", skuespillerens metier, "Naturalisme" i teaterkunsten, tidens mange sceniske reformforsøg, scenekunsten i Danmark, Norden og pă de store centraleuropæiske scener, samt skuespillerens uddannelse hjemme og ude. Desuden analyserer han utallige specifikke teaterroller og deres fortolkningsmuligheder samt giver levende beskrivelser af datidens teaterpublikum og teater- og kulturpolitiske forhold.

Bangs alsidighed som teateressayist er derfor enestáende i dansk teaterhistorie, fordi han med ligelig faglig indsigt, analytiske evner, nysgerrighed og indfolingsevne behandler disse rigt varierende emneomrăder af scenekunsten med en altid konstant og usvækket inter- 


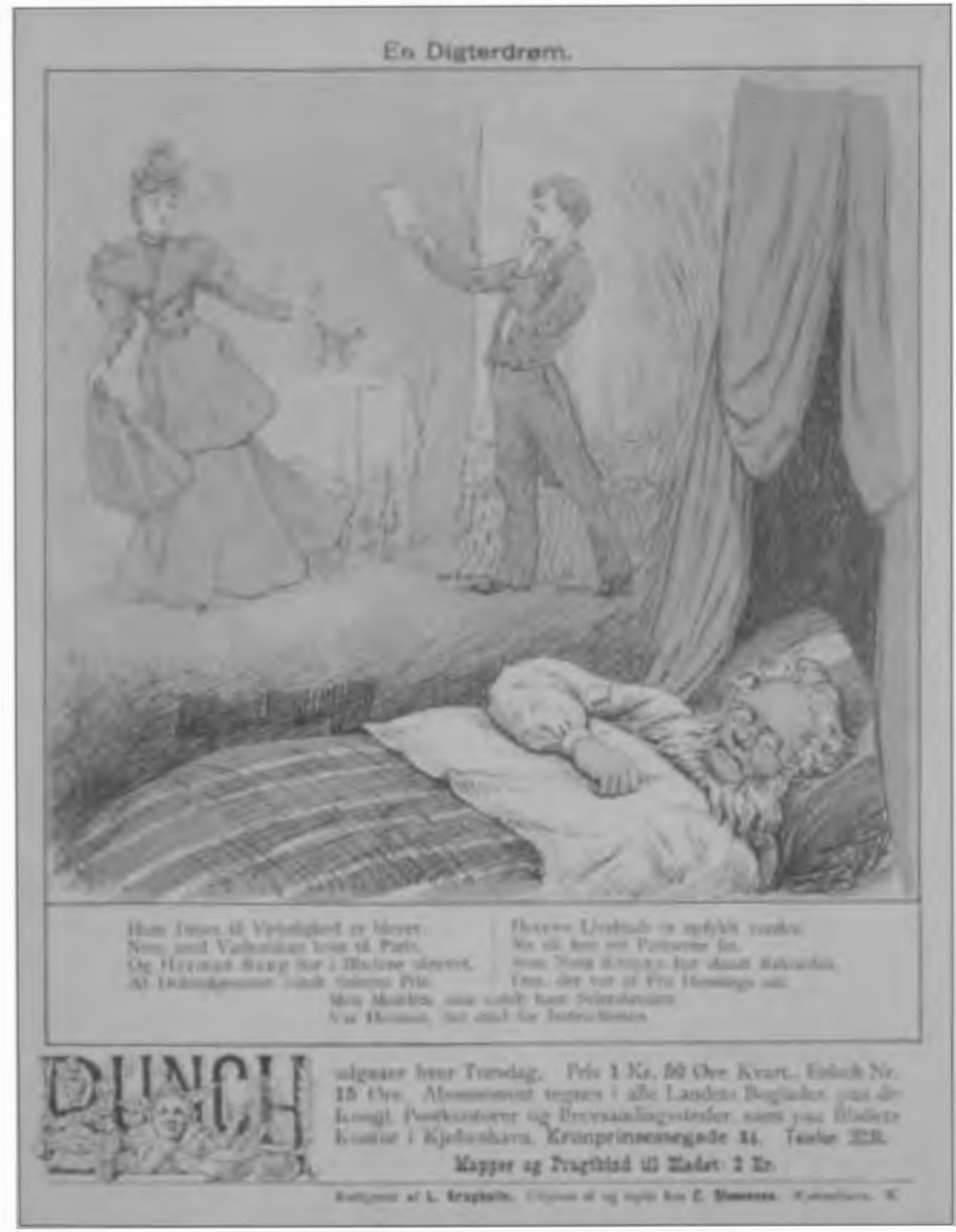

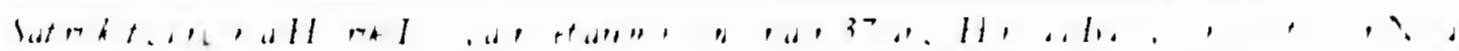

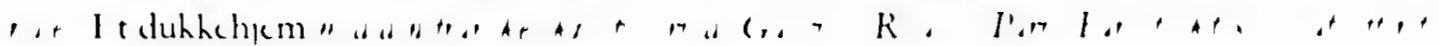

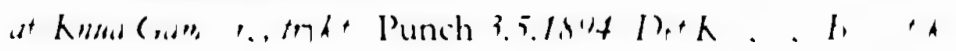

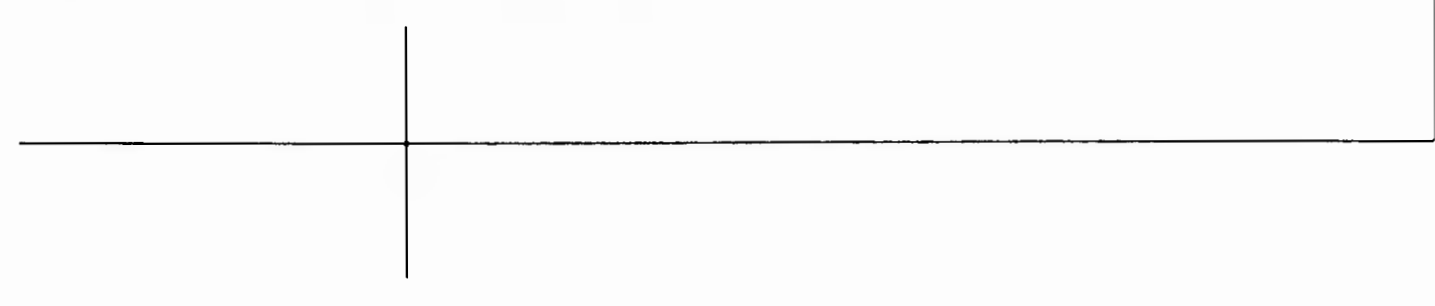




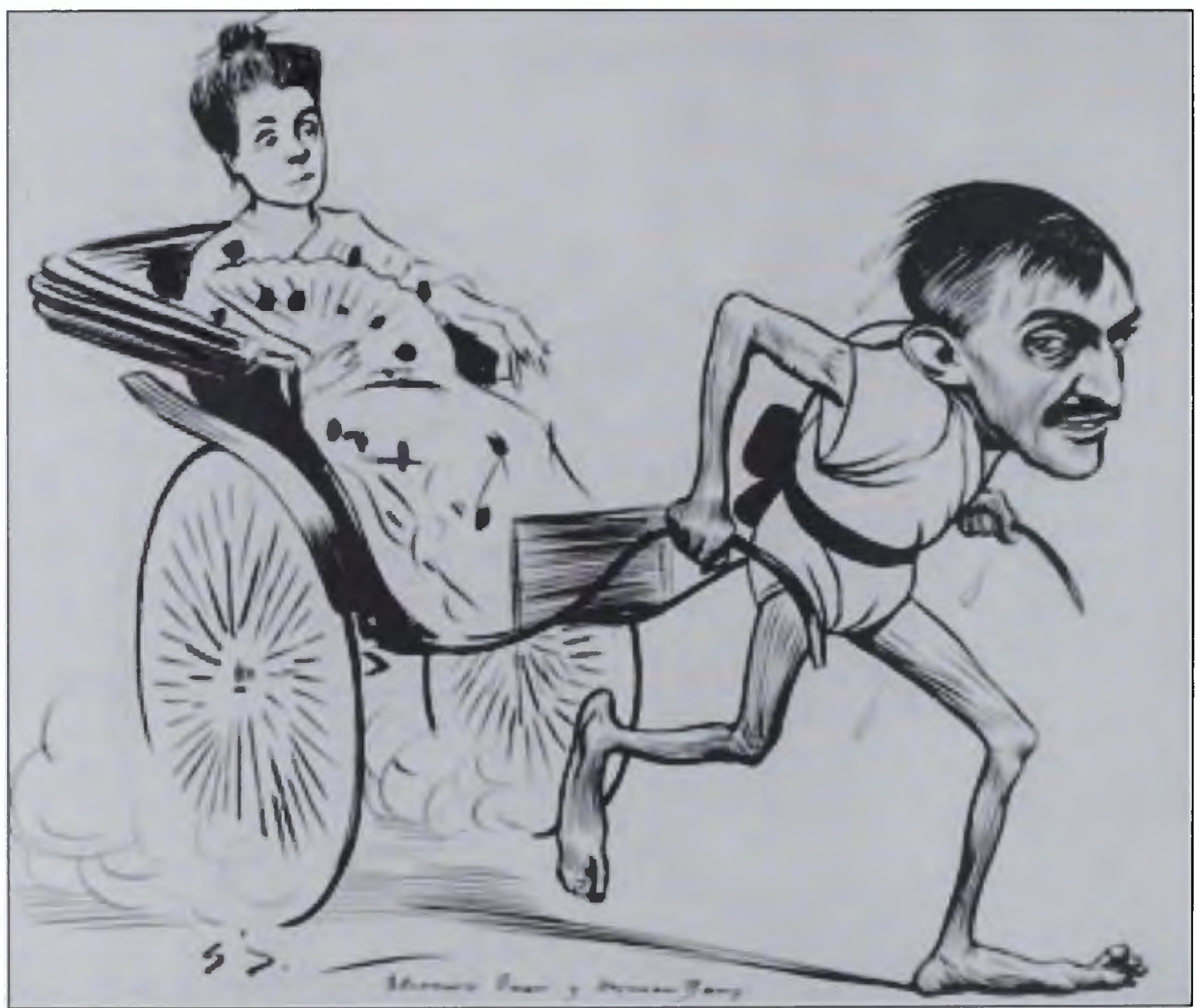

Satirisk tegning af den 49-arige Herman Bang som rickshaw'kuli for den italienske skuspillerinde Eleonora Duse under bendes gastespil $i$ Kobenhain. Originaltegning af Sopbus Jïrgensen, trykt $i$ Ekstrabladet 22.1.1906 (Det Kongelige Bibliotek).

esse helt frem til sit sidste leveår.

Om skuespillerens metier har Bang ligeledes talrige debatindlæg med ofte meget personlige replikker. I en artikel i Nationaltidende (1. november 1882) fremforer han den for ham helt uundgåelige forudsætning, at skuespilleren - selv nảr denne optræeder under dække af en maske - altid "giver og bliver sig selv". I samme artikel fremforer han synspunktet, at skuespillerens kunst forst og fremmest er "en Form, hrorunder et Menneskelivs Oplevelser skænkes os". Bang synes dermed klart at distancere sig fra samtidens fremherskende opfat- telse - især indenfor fransk teater - af skuespilleren som forst og fremmest et reproducerende "Neutrum". Overfor dette kunstsyn står her hans klare udsagn om scenekunstnerens hele metier:

Enhver sand Kunstner giver i Virkeligheden enhver Fiber af sig selv, hele sit Menneske i sin Kunst og gior kun Virkning paa denne Betingelse, saa Skuespilleren er ogsaa her ligestillet med alle sande Kunstnere.

Bangs opfattelse og definition af begrebet "Naturalisme" i teaterkunsten udtrykker han ligeledes tidligt i sin karriere som teateressayist. Han sammenfatter 
allerede i en anmeldelse i Nationaltidende (2. april 1884) sin definition af "det nye naturalistiske Drama" i det moderne teater med disse ord:

Paa Theatret som i hele Kunsten shal Problemerne kun existere skjulte i de Menneskeskixbner, som forklares for os. Dramact shal viere et Stykke forklaret Liv intet andet. Romanens og Dramaets Stof er det s.mme: Livets Stof.

I samme essay anviser Bang rejen frem for den ny tids naturalistiske forfattere, idet han fremsxtter folgende rad til det fremstormende naturalistiske teater:

Den Dag, da de nye Forfattere uden at fore i Marken anden Polemik end den, der ligger i Skildringen selv, griber Livet ag skenker on det sande Billede paa Secnen, vil Publikum opurge disse nye Dramacr. Men endnu have vore dramatishe Iorfattere hun nalet ()verfladen af Lact, ogefter at have ladet Situationen og spexding i Stikken, eie de kun Di.llogen til at bode par, hrad de have forladt. Thi den sjexlelige Dybde, den store Klarhed i Karahteren, hase de ihe opnaaet.

For Bangr rar det naturalistiske teater derfor a hol grad et eporesemal om som han shriver i en sencre forestill ingsanmeldelse i dagbladet Kubenhan'n (8. september 19(15) - at lade "det skiftende Hjartets og Nervernes Liv" skinne igennem", ligesom nar "Blodet lyser i en hrid Haand, der holdes for en Lampe".

Bangs forstaelse af begrebet naturalisme inden for scenens kunst som den sande menneske-fremstillende kunst fremstar nok her i sin allermest lysende klarhed.

\section{Nye Herman Bang-udgivelser i 2007:}

\section{Stoppet i farten - Herman Bang i karikaturens troldspejl}

Udgivet af Dag Heede, Knud Arne Jürgensen, Torben Lund og Sten Rasmussen, med en efterskrift af Mette Wingre (Gyldendal, $\left.2(11)^{-}\right)$.

Stille eksistenser spiller en central rolle i Herman Bangs forfatterskab, men nogren stille eksistens var han pa ingren made selv: Professionelt spandte han vidt - forfatter, journalist, kronikor, endy ist, sceneinstruktor, oplixer og anmelder or produktiviteten var enorm. Allerede med dehutromanen Hadi inse birittersakte han storr opmarksombed, og bengen bles

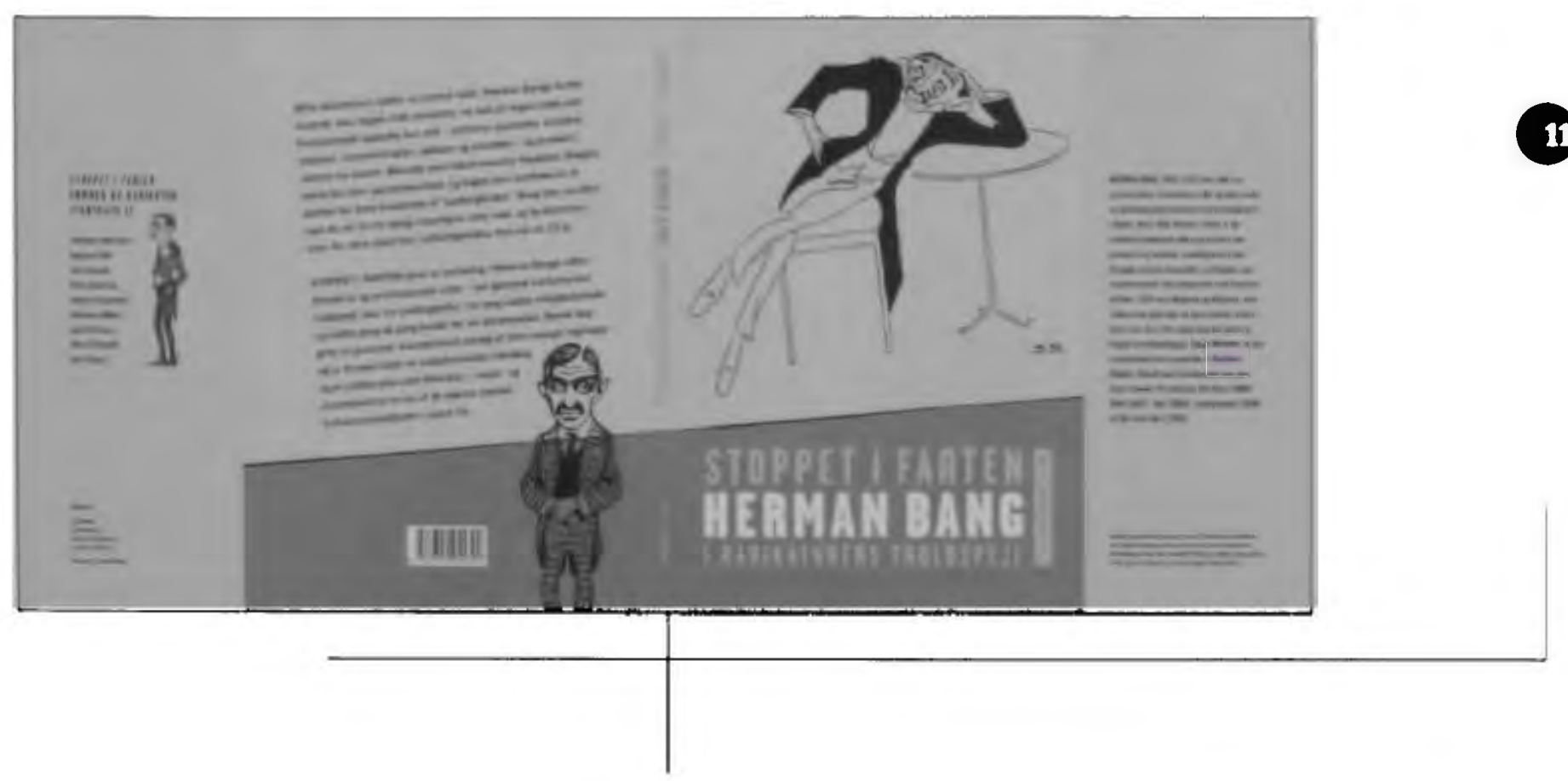


konfiskeret af politiet for dens krænkelse af "sædeligheden". Bang blev straffet, men da var forste oplag naturligris revet rak, (og forfatterens navn for alvor slaet fast $i$ offentligheden. Han var da 23 ar.

$$
\text { Stoppet i farten giver en indforing }
$$

i Herman Bangs udfordrende liv og professionelle virke - set igennem karikaturens troldspejl. Han var yndlingsoffer i en lang rakke vittighedsblade og matte gang pa gang betale for sin berommelse. Denne bog giver et generost, kommenteret udvalg af disse mange tegninger og er dermed bade en underholdende billedbogr og et stykke alternativ litteratur-, teater- og pressehistorie om en af de storste danske kulturpersonligheder i nyere tid.

\section{Herman Bang: Vekslende Themaer}

I-IV, udgivet af Sten Rasmussen (Det

Danske Sprog- og Literaturselskab, C. A.

Reitzels forlag, 2(1)7)
I arene 1879-84 skrev den unge Herman Bang 210 sondagskronikker, sakaldte feuilletoner, under fxllestitlen I ekslende Tbemaer. Kronikkerne betegner et hojdepunkt inden for dansk journalistik og er en broget blanding af reportager, stemningsbilleder, essays, portræetter og anmeldelser, der giver læseren et enestaende indblik i Kobenhavnerlivet i $188(1$ 'ernes forste halvdel. Den ekspanderende storbys medieverden, dens forlystelsesliv og dagligdag er her fastholdt for eftertiden $\mathrm{i}$ et artistisk forfinet sprog, hvis yderpunkter er causeriets overstadige humor on den sociale reportages stengra alvor.

\section{Dramaturgiske Pennetegninger.} Herman Bang som teateressayist, En antologi

Udgivet og kommenteret af Knud Arne Jürgensen (Syddansk Lniversitetsforlag, $2(0) 77$.

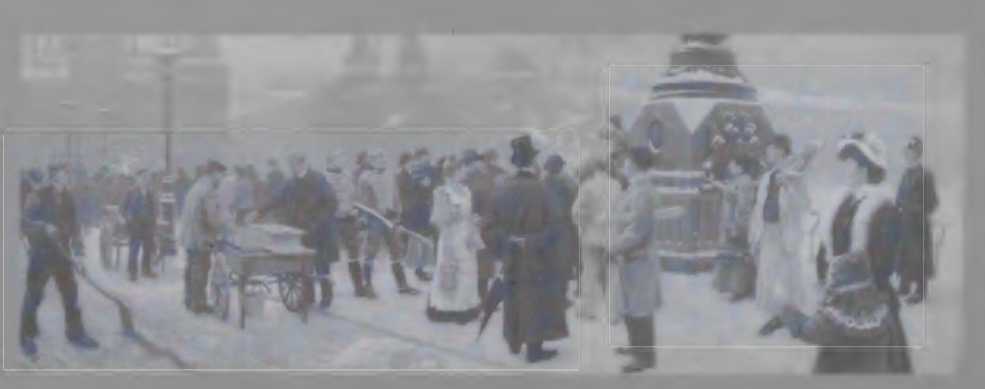




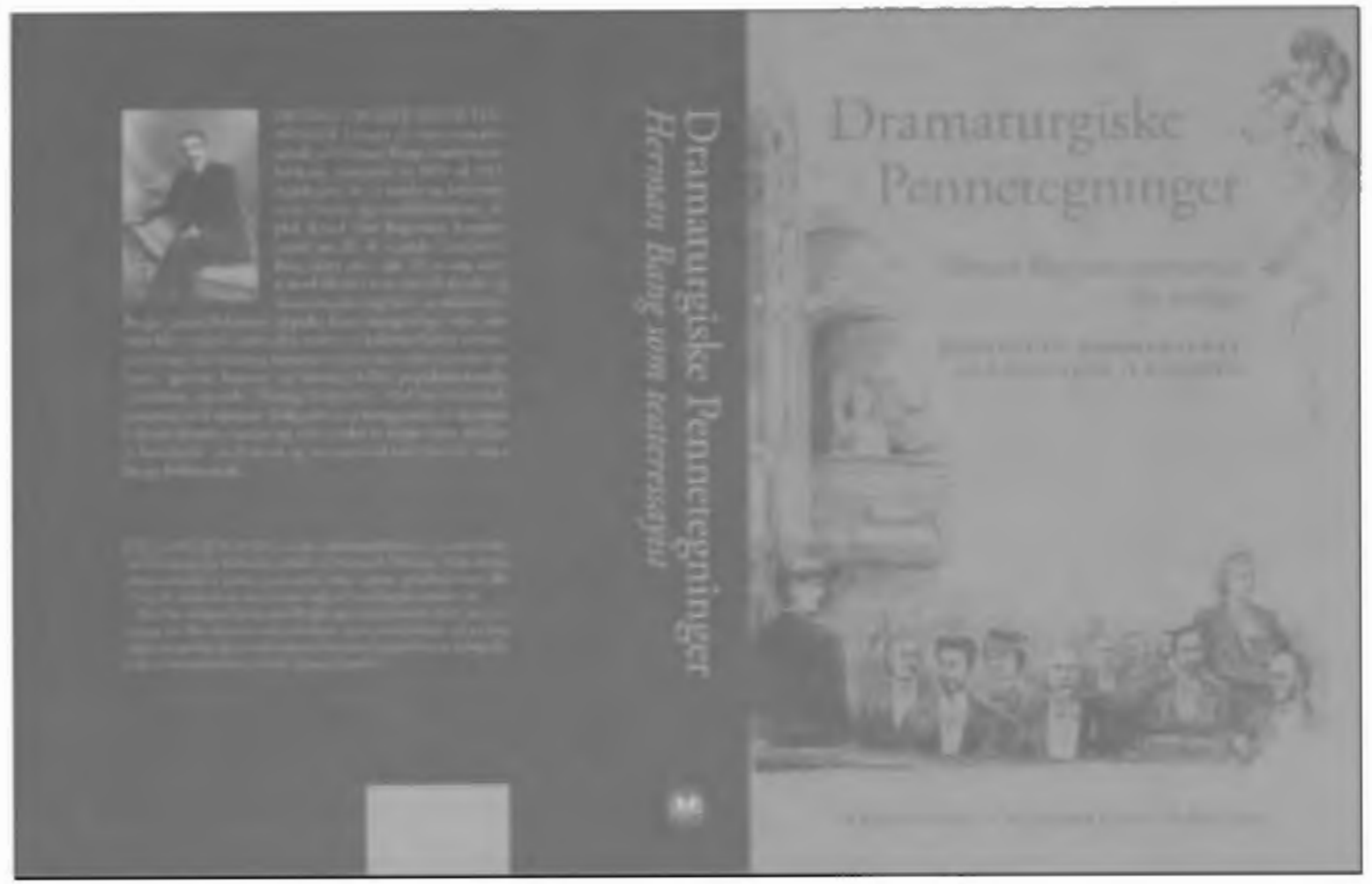

Dramaturgiske Pennetegninger bringer et reprasentativt udvalg af Herman Bangs teaterjournalistik og -essayistik fra 1878-1912. Antologien, der er samlet og kommenteret af teater og musikhistorikeren, dr. phil. Knud Arne Jürgensen, kommer rundt om alle de sceniske kunstarter, Bang skrev om i sine 33 år som aktiv teaterskribent i mere end tres danske og skandinaviske dagblade og tidsskrifter. Bangs teaterrefleksioner afspejler hans mangesidige virke som anmelder, essayist, journalist, teater- og kulturpolitiker, personportrattør, instruktør og iscenesatter samt hans observationer om opera, operette, koncert- og visesang, ballet, populzrkulturelle sceneshows og andre offentlige forlystelser. Med sin omfattende teateressayistik opnåede Bang mere end mange andre af datidens kulturskribenter; samlet og vejet under ét udgør disse artikler et hovedværk sável i dansk og international teaterhistorie som i Bangs

\section{forfatterskab.}

I tilknytning til antologien lægger Det Kongelige Bibliotek på 150-års dagen for Herman Bangs fodsel den 20. april 2007 en net-bibliografi med hans samlede teaterskribentvirksomhed op pá sin hjemmeside < www.kb.dk/da/publikationer/online/fund_og_forskning $>$.

Net-bibliografien er opstillet kronologisk efter udgivelsesåret/udgivelsesmåneden/årgangsbindet $o g$ medtager Bangs samlede trykte skribentvirksomhed i Danmark, Norge, Sverige og Tyskland, der omhandler emnet scenisk kunst $\mathrm{i}$ bredeste betydning: drama (herunder Bangs egne sceniske arbejder og hans utrykte oversattelser af fremmede dramatikeres varker), opera, operette, ballet, musik, visesang, koncerter, cirkus, varieté, tryllekunst etc. Samtlige artikler er medtaget $i$ fortegnelsen efter primar registrering. 
indledes med den fulde titel (i kursii) på bogen/avisen/tidsskriftet, hrori artiklen/artiklerne findes trykt. For dagblades vedkommende er hrer artikel anfort med publikationsdato efterfulgt af navnet pă en evt. rubrikoverskrift og artiklens hovedtitel gengivet i eksakt transskription efter originalen. For tidsskrifters redkommende anfores oplysninger (i parentes) om àrgang, bind/hefte/nummer, dato, sideangivelse(r) samt eventuel(le) tilhorende illustration(er). Til de artikler, hvis indhold ikke entydigt og fuldstændigt fremgăr af hovedtitlen, er der tilfojet en kortfattet beskrivende indholdsnote $[i$ skarp parentes].

I de tilfælde, hvor Herman

Bang har anvendt pseudonym/mærke, er dette anfort (i parentes) ved slutningen af artiklens registrering. En samlet oversigt over de mærker og pseudonymer, Bang har benyttet i sin trykte teaterkritik, -journalistik, og -essayistik, findes anfort umiddelbart efter fortegnelsen.

Usignerede artikler er kun medtaget $\mathrm{i}$ fortegnelsen, săfremt der foreligger veldokumenterede oplysninger om, at Bang reelt er forfatteren, enten $i$ form af en omtale af de pågxldende artikler $i$ hans egne breve eller $i$ hans ovrige trykte artikler, $\mathrm{i}$ avishonorarprotokoller og lignende samtidige kilder.

Bangs talrige anonymt trykte dagbladsnotitser af forskelligt dagsaktuelt eller anekdotisk teaterindhold er dog ikke medtaget i fortegnelsen, idet disse ultrakorte dognfluenotitser har en udpræget karakter af petit-journalistik og dermed falder for den bagatelgrænse, der er sat for fortegnelsen. Disse avisnotitser findes oftest trykt under rubrikoverskrifter som "Mosaik", "Charivari", "Fra Theaterverdenen" o. lign.

De artikler, der omhandler personer, som omtales igen i Bangs senere teaterskribentvirksomhed, er forsynet med henvisninger til disse senere artikler forste gang de păgældende personer optræder i fortegnelsen. Artikler, der blev genoptrykt i uændret eller delvis ændret form i Bangs egen levetid er ligeledes forsynet med henvisninger til disse senere genoptryk forste gang de págældende artikler optræeder i fortegnelsen.

Litteratur benyttet i forbindelse med udarbejdelsen af fortegnelsen er anfort under overskriften. Anvendt litteratur til slut $i$ fortegnelsen.

Artikler mærket med asterisk (*) i bibliografien findes genoptrykt og kommenteret af Knud Arne Jürgensen i antologien Dramaturgiske Pennetegninger.

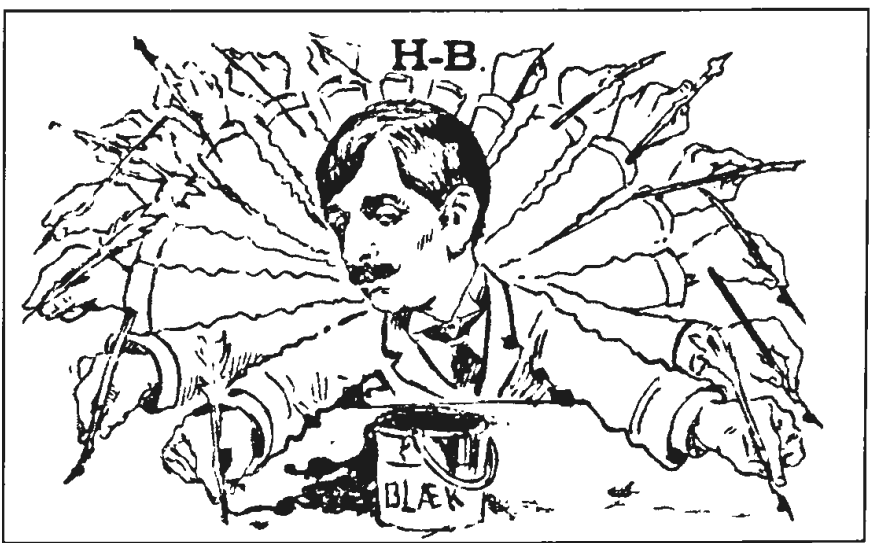

Satirisk tegning af den mirefittige teateressavist Herman Bang, trikt i morskabsbladet Punch (23.10.1890). 